\title{
Water and employment for all?
}

LIKE those in what used to be the Soviet Union, India's policies are driven by a sucession of five-year plans. But the eighth plan (1992-97), now in force, differs from its predecessors in its open declaration that its purpose is more indicative than prescriptive. That reflects India's move away from central control of the economy and much else.

But the language of this change is interesting. In his introduction to the latest plan, the Prime Minister, Mr P. V. Narasimha Rao (who is chairman of the Planning Commission and of much else) recognizes that there are many areas in which development can best be ensured by freeing them of unecessary controls", but then insists that India's growth and development cannot be left entirely to the market mechanism. The market, he says, may be able to balance supply and demand, but not supply and need; planning is essential for taking care of the poor and downtrodden.

There will be plenty of those. The plan says frankly that if the impoverishment caused by rapid population growth is not halted, it will never be possible to render social and economic justice to millions of our masses. The planners accept received wisdom that this will have to be done by education, health services (to reduce mortality) and by provision of paid employment. (Ambitiously, they make full employment by the end of the

ment in India is growing quickly and overseas trade is picking up. The snag is that it has been necessary to protect the domestic economy by fiscal rather than physical means: the rupee has been devalued (to Rs 31.00 to the US dollar) but is convertible, the banks charge 18 per cent interest on commercial loans and government spending is being kept on a tight rein. Businessmen delight at the erosion of the licensing system and at the way in which that has robbed pettifogging bureaucrats of the power they previously enjoyed, but complain that foreigners are snapping up Indian assets too cheaply because interest rates in India are so much higher than elsewhere in the world.

The Rao government must now decide whether to persist with its reforms and, in particular, whether to begin denationalizing the major industries and the banks. The state assembly elections in Northern India at the end of last month will not have helped to clear its mind: both the government party, the secular Congress(I) (where TIU stands for 'Indira'), and its chief rival, the BJP (a Hindu party) did less well than they might have done, but the government was not so severely punished that it will be compelled to count its century one of their goals.)

For the rest, the objectives for the current five-year plan are the provision of safe drinking water for everybody (electrification of the villages was the target of the two previous five-year plans), the diversification of agriculture (partly for the sake of the exports it will generate) and the improvement of the infrastructure of the growing cities (in which 25 per cent of Indians now live).

The new plan pencils in a population growth rate of 1.87 per cent a year in 1992-97, suggests that a net reproduction rate of unity (which implies mere replacement of the population) would be attained roughly a quarter of a century from now, but that, because of the predominance of young people in the population then, numerical stability will be reached only towards the end of the next century. Prudently, the planners do not say what the stable figure will be.

On science and technology during the five-year period, the plan says that attention should be concentrated on projects contributing to its declared social goals as well as to the improvement of industrial production. But the plan also declares that research projects that would give India an international reputation should be backed, as should be the projects (such as India's interest in space) already accepted as strategic objectives.

\section{economic reforms mistaken.}

Yet what the government does about economic reform in the next two years (before the next general election) will be crucial to India's future, and to that of Indian science. The only known way of quickly generating the resources required for social reconstruction is the market economy, but dashing for full economic liberalization will bring a painful social upheaval in its own right. The Rao government is in much the same cleft stick as many of those of Central Europe, faced with the task of unwinding a command economy without damaging the social fabric irreperably.

What will the reforms do for Indian science? The chief effects so far have been painful and unwelcome: frozen and even shrinking budgets caused directly by the need to keep government spending under control. Universities and basic research institutes are the chief victims. University budgets (in rupee terms, without allowance for inflation) have been frozen for two years and there is no relief in sight. And many research laboratories are now being required to arrange that at least half of what they spend each year will come from sources other than their sponsoring agency by 1997 . As well as the reduction of public spending that will result, one objective is to persuade Indian companies to take research more seriously. The snag is that some laboratories are incapable of feats such as these, and that the new policy represents a sharp break with the post independence tradition that the 'centre' (the collective name for the union government and its agencies) decides and carries out the research that India needs.

The reforms thus require decentralization of decisions on research, for which the machinery has fortunately been constructed in the past few years. Indeed, there have been striking changes in the past decade. Laboratory directors unable to make simple decisions because they had (and wished) to refer to Delhi are now far fewer. But it remains to be seen whether the public laboratories (and the government agencies that support them) have entirely shaken off their old ways of working, the effect of which was commonly to allow ambitious projects to continue beyond the point of vanishing success without responsibility being attributable to anybody. The most serious danger in present circumstances is that attempts to create in India a replica of one of the many, and mostly false, replicas of Japan's Ministry of International Trade and Industry will prove to be another scheme for enabling the centre to back research projects of its own fancy, Twinners' and, as often, losers.

In passing, the parallel between the present problems of the research enterprise in India and in Britain cannot fail to capture the attention. For different reasons (the logic of economic reform and impatience respectively), both governments are seeking closer links between the research they support and industry more generally. In each case, researchers are required to take the initiative, winning first the interest of industrial partners and then, with luck, their financial support. If anything, India's problems are the simpler. Maybe on this occasion, Britain has more to learn from India than the other way round.

Where the effect of India's economic reforms on the pattern of research will in the long run be most marked is in its policy of 'self-reliance'. Self-suffiency (which means 'self-contained') is no longer a credible, let alone a desirable, goal. But India has taken from the outset in 1947 the view that it must be able to rely on its own resources for the technological skills it considers vital to its survival. That explains the energy put behind the engineering of the Green Revolution, which has rid the government of the need to beg annually for credits with which to avoid famine somewhere in the country, and in the process to be preached at by Western politicians on matters as different as relations with the Soviet Union (close 